\title{
IMPROVING THE COLLEGE STUDENTS' SPEAKING SKILL OF POTENSI UTAMA UNIVERSITY THROUGH TOTAL PHYSICAL RESPONSE METHOD
}

\author{
Dwi Suci Amaniarsih \\ English Department,Faculty of Politics and Education, Potensi Utama University, Indonesia \\ Email : amaniarsih86@gmail.com \\ Firdayanti Firdaus \\ English Department, Faculty of Politics and Education, Potensi Utama University, Indonesia \\ Email : firdayanti.firdaus95@gmail.com
}

\begin{abstract}
The purpose of this study is to find out how the application of the Total Physical Response method in an effort to improve English language skill. The subjects in this study were the college students of Potensi Utama University in Medan. While the object of this research is the application of the TPR method, to improve students' skill to speak English. Based on the results of the study it can be seen that the percentage of the results of the completeness of the students' scores between the preliminary conditions and the first and the second cycle has increased. In the preliminary conditions the percentage of completeness in student grades is only $24 \%$. In the first cycle, the percentage of completeness of students' scores increased to $40 \%$, while in the second cycle there was a significant increase to 68\%. If a comparison is made between students 'speaking abilities during the preliminary conditions and after the application of the TPR method, there is a $53 \%$ increase in students' English speaking skill using the TPR method. Thus it can be said that the use of the $T P R$ method can improve students' English skill in the procedure text.
\end{abstract}

Keywords: Speaking skill, Total Physical Response method

\section{INTRODUCTION Background}

English is a very important language in the international world, especially in the era of globalization. The role of English is very important in mastering the science of communication and interacting directly with the global world. English as a foreign language or EFL (English as a foreign language) in Indonesia is taught from the level of Junior High School to Higher Education in the hope that students are able to master the four basic skills of English, namely: speaking, reading, listening, and writing. Among the four English language skills mentioned above, speaking skills or Speaking skills taught in Higher Education are considered difficult for most students. This is because speaking skills require vocabulary and expressions and correct pronunciation (pronunciation) of students in expressing their ideas, thoughts, and experiences as a whole and communicative.

According to Solikhah (2015), English speaking skill (freshmen) in Indonesia is generally lacking due to diverse backgrounds. Important causes of this problem include students lacking standard mastery in basic knowledge aspects, in the form of vocabulary and grammar and mastery of academic literacy, especially reading and writing, which is also lacking. The limitation of vocabulary mastery results in students having difficulty expressing ideas and intentions of expressions towards certain goals. The limitations of grammar make it difficult for students to compile sentences that will be said so that students make mistakes.

This also happened to the students from Potensi Utama University in Medan. Based on the results of observations and interviews that researchers conducted with several students, it was found that there were still many students who were not able to speak English. This is evident when lecturers invited them to communicate in English, many of them are not able to respond and did not understand what was delivered. The cause of this problem can occur due to several reasons, most likely due to the overly tense learning situation, thereby reducing student motivation in attending the lesson. In addition to these factors, 
the factors to be considered in the process of teaching skills of speaking English is the application of the approach (approach) and the appropriate method so as to change the paradigm of students who think that talking is difficult, and make them afraid of making mistakes especially in grammar and expressions. In this case students need to be trained to dare to speak and express their ideas with spoken language.

This study tried to find a solution to overcome the problems faced by students in learning activities to teach Speaking Skill. To help improve the skill of students to speak in English, the researchers used the Total Physical Response (TPR) method. Total Physical Response Method is a very good method for improving speaking skill for students.

The Total Physical Response (TPR) method is a language teaching method developed by James Asher, a professor of psychology at the University of San Jose California. This method is a language teaching method that is widely applied by instructors of foreign languages (foreign language) in the classroom. This method is one method of language teaching that is very popular and relevant to be applied in teaching. This method is not only suitable for small children, but it can also be effectively applied to teaching a teenagers (adolescent) and adults with different levels and levels.

This method contains elements of game movement so that it can relieve stress on students because the problems faced in the lesson are especially when learning a foreign language, and can also create a positive mood for students who can facilitate learning so as to increase participants' motivation and achievements students in the lesson. Educators have an active and direct role in applying this method. Students in the Total Physical Response (TPR) method. Has a main role as a listener and actor. Students listen attentively and respond physically to the instructions given by educators both individually and in groups.

TPR was developed by James Asher, a professor of psychology at San Jose State University, California in 1960. In TPR, understanding must be supported by listening skills because it will make it easier for students to understand and a student will learn to recognize words or sentences from what they hear.

On the basis of these considerations, this study focuses on "Improving the college students' speaking skill of Potensi Utama University through Total Physical Response Method"

Speaking in general can be interpreted as conveying one's intentions (ideas, thoughts, and contents) to others by using spoken language so that the intent can be understood by others. Speaking in essence is a process of communicating, because it involves transferring messages from one source to another.

Speaking skills are essentially skills to reproduce the flow of the sound articulation system to convey the will, needs of feelings, and desires to others. This skill is also based on the confidence to speak naturally, honestly, correctly, and responsibly by eliminating psychological problems such as shame, inferiority, tension, weight of the tongue, etc. (Iskandarwassid and Dadang, 2011: 241).

Speaking skills are productive skills that are integrated. Productive means that when speaking, people use spoken language to convey a conversation, in the form of thoughts, ideas, and feelings. Integrated means at the time of the conversation, there was a merger of a number of abilities that became a component of speech, mastery of the content of speech, mastery of techniques, and appearance of speech.

From some of the meanings that have been mentioned, it can be concluded that speaking skills are a process of expressing, expressing, and conveying ideas, thoughts, ideas, or contents to others by using spoken language that can be understood by others.

Speaking skills have a very important role in everyday life. With speaking skills, students will be able to convey ideas, thoughts, ideas, and feelings to others. According to Iskandarwassid (2011) the purpose of speaking skills will include achieving the following:

1. Ease of Speaking

Students must have a great opportunity to practice speaking until they develop these skills naturally, smoothly, calmly.

2. Clarity

Students speak precisely and clearly, both articulation and diction of the sentences.

3. Responsible

Good speaking exercises emphasize the speaker to be responsible for speaking appropriately, and thoughtfully. 


\section{Establish Critical Hearing}

Speaking exercises developing quick and critical listening skills are also the main goals of speaking.

\section{Forming Habits}

Speech habits cannot be achieved without the habit of interacting in language learned or even in mother tongue.

Total Physical Response (TPR) is a language learning method developed by James Asher, a psychologist from San Jose State College, United States in the 1960s. Total Physical Response Method is a language teaching method that is built based on the coordination of speech and action through motion activity. Basically the Total Physical Response (TPR) method consists of structuring or complying with orders given by the instructor / teacher that involve a clear physical response. For example, if the instructor says to stand, students in the class stand or if the instructor says to sit, then the students in the class sit down.

Fachrurrozi et al (2016: 123) explain that the TPR method is a method of language teaching that is built on speech coordination and action, this method attempts to teach language through physical activity or motor activity (movement).

Total Physical Response is a language teaching method that is built based on coordination and action said through activity movements. Basically, Total Physical Response consists of management or actions given by the instructor or teacher relating to physical response clearly. The results of the application of the Total Physical Response method are expected to provide benefits for students to understand easily and motivate in speaking through teaching strategies using Total Physical Response, and for teachers to understand the ways to implement the best teaching strategies using Total Physical Response and the best choice in the learning method.

From the above opinion, it can be concluded that The Total Physical Response (TPR) method is one of the language teaching methods built based on speech coordination and action

The Total PhysicalResponse method certainly has advantages and disadvantages in its application, including:
1. The advantages of the Total Physical Response (TPR) method

a. Language learning is fun for educators and students.

b. Students feel free from feelings of stress or stress when learning.

c. Learners have long-term memory of what they have learned, this is due to the empowerment of the right brain and left brain.

d. This method allows meaningfulness in learning the target language.

e. Delays talk until students know enough and understand the target language to give birth to the confidence of learners.

f. By emphasizing understanding, this method can easily be combined with other methods that are based communicative approach.

2. Disadvantages of the Total Physical Response (TPR) method

a. Language rules are so complex that not all forms of language can be taught by using commands.

b. Some students feel reluctant when asked to demonstrate a movement, especially if they feel uncomfortable or feel confused in the class that uses this method.

c. Foreign language teaching techniques in this method are more suitable and limited to beginner level teaching.

d. The application of this method requires / requires educators who are able to speak in the target language well and meaningfully, and not just structure.

\section{RESEARCH METHODS \\ Types of research}

This study is a type of Classroom Action Research (CAR). Class Action Research is a reflective research which is based on real conditions which are then searched for problems and followed up by carrying out planned and concrete actions measurable (Suwandi, 2009: 10) . According to Arikunto (2010: 4) it is revealed that Classroom Action Research (CAR) is a reflection of learning activities in the form of an action, which is deliberately raised and occurs in a class simultaneously. So Classroom Action Research is research actions taken in class with the aim of improving the process learning. 
The purpose of this study is to examine the problems related to the behavior of a particular person or group in a particular location with a careful review of a treatment and examine the extent of the impact of the treatment and eliminate the negative aspects of the perpetrator being studied. In this study, action research was conducted to improve students' English speaking skill through the Total Physical Response method

\section{Place of the Research}

This research was conducted at the University of Potensi Utama Which is placed at Jalan KL. Yos Sudarso No. 3 A, Tanjung Mulia Medan.

\section{Research Subjects and Objects}

The subjects in this study were the fourth semester students of the English Language Study Program at Potensi Utama University. While the object of this study is the application of the Total Physical Response method, to improve students' English speaking skill

\section{Source of the Data}

The data used is qualitative data, in the form of primary data and secondary data. Primary data is obtained directly from the results of observations and interviews. Secondary data is obtained from documentation, namely from the relevant institution or organization as additional data.

\section{Research design}

The design of this study is Classroom Action Research conducted collaboratively. In collaborative research, the party taking action is an English subject lecturer for students of the English Language Study Program at Potensi Utama University. Whereas those who observe the ongoing process of action are researchers. This study uses the action research model of Kemmis and Taggart, which is spiral in shape from one cycle to the next. According to Kemmis and Taggart in Wiriaatmaja, there are several stages in this research, namely:

1. Planning (plan)

2. Action (act)

3. Observations (observe your)

\section{Reflections (Reflect)}

The implementation of the research was carried out by means of collaboration, namely research involving other people besides the researcher, namely as observers (colleagues). The researcher used the step flow (planning, action, observation, and reflection presented in two cycles).

This research was conducted in two cycles. The cycle is stopped if the data displayed in the field is saturated, meaning that if there is an increase in the skill to speak English from students in the learning strategy the total physical response method.

\section{Stages of the Research \\ Stage I Cycle Research \\ 1. Planning}

At this stage the researcher prepares the implementation plan of the learning model program for the total physical response method:

a. Permit the University and Lecturers of related subjects to apply the Total Physical Response method in English courses

b. The researcher conducted interviews with English Language Lecturers and students

c. The researcher coordinated with English Language Lecturers related to the place and time of the study

d. The researcher prepares a theme or topic to be applied in the Total Physical Response method later

e. The researcher coordinated with the collaborator, namely the lecturer in English courses related to the theme and how to implement the Total Physical Response method later when KBM takes place

The researcher prepared the observation and interview guideline sheets needed in the study

\section{Action}

The action in the first cycle is carried out in 2 meetings, namely every 1 week. The action stage is carried out by English Lecturers with researchers in applying the learning method of Total Physical Response. The actions taken in each cycle are:

a. Preliminary

Lecturers give an explanation of what the Total Physical Response 
method. And also divides all students in small groups consisting of 4-5 people per group. After that, the lecturer gave each group a theme prepared by the lecturer with the researcher.

b. Core activities

After students are divided into small groups and have received themes, then they compile or make a procedure text related to the theme that has been given, After compiling the procedure test, each group member tells their text in front of the class by performing their phisyc response using the tools the need. After they perform their procedure text in front of the class, the lecturers gave their input. In this stage, researchers function as observers of activities and conduct interviews.

c. Closing

Lecturers give appreciation for groups that perform well and in front of the class.

\section{Observation}

Observation is carried out during the implementation of the action by using the prepared observation sheet and recording the events that are not contained in the observation sheet by making a field note. The things observed during the implementation of the action are activities as long as the learning model of the Total Physical Response method is carried out. In addition, interviews were also conducted using interview guidelines. Interviews were carried out on students who took part in learning the Total PhysicalResponse method after implementing the action.

\section{Reflection}

At this stage the researcher and lecturer conduct an evaluation of the implementation of actions in the first cycle, including analysis, synthesis, meaning, explanation, and conclusion of the data and information collected. The data and information are used as material for consideration in planning the implementation of the Total Physical Response method of learning in the next cycle. If the expected results have not been achieved, then repairs are carried out and carried out in the second cycle. The next cycle is carried out, if the students have not shown a number of characters who are indicators of fluent English. If in the first cycle of action the results have been reached then the second cycle will still be carried out to prove that the results are not a coincidence, but are the result of applying the Total Physical Response method learning.

\section{Stage of Cycle II Research}

The cycle II action plan is intended as a result of reflection and improvement in the implementation of the program in cycle I. The stages of action in cycle II follow the stages of the action cycle I.

\subsection{Data collection technique}

The data collection techniques used are:

1. Observation

In this study there are two guideline observations, namely observation for student activity and observation sheet implementation of learning methods Total Physical Response. The observation sheet for students is in the form of observation sheets for performance appraisal (process) and observation sheets for student learning activities. While the observation sheet for the implementation of the program is an observation sheet that is used to observe the implementation of the actions carried out by lecturers and researchers.

2. Interview

Interviews were conducted by asking the English Lecturer and students regarding the implementation of the Total Physical Response method in class in order to improve the skill to speak English.

3. Documentation

Documentation is obtained from the results of observation sheets, interview sheets, field notes, student lists and photographs during the program

\subsection{Instrument of the Research}

1. Researcher 
In this study, researchers are instruments because researchers as well as planners, implementers, data collectors, data analyzers, and become research reporters

2. Observation sheet

Observation method is done to observe the class atmosphere where the learning takes place. Observing student enthusiasm in following the learning model of the Total Physical Response method in class.

3. Interview guidelines

This interview guide is used to determine the response or response of lecturers and students about learning the Total Physical Response method in order to improve students' English speaking skill.

4. Documentation

The documentation used in this study is the lesson plan program, a list of names and the scores of English speaking subject of the students, learning about the document adopted by the previous lecturer, and documentation for the implementation of the learning model Total Physical response method runs.

5. Field Notes

The field notes method is used to record the class atmosphere during the learning process. Matters recorded include:
a. Student activeness in the learning process
b. Lecturer Activities in applying the learning method of the Total Physical Response method

\subsection{Data analysis technique}

The data analysis technique used is data reduction, namely data selection activities, data simplification and transformation from field notes. Presentation of data in the form of a collection of information in the form of narrative tests that are compiled, arranged and summarized so that they are easy to understand. This was done in stages and conclusions were made by means of discussions with collaborative partners. To ensure the consolidation and correctness of the data collected and recorded in the study, triangulation was used

\subsection{Data validation}

Researchers in examining the validity and reliskill of data using triangulation and member check techniques, triangulation as a data collection technique that is combining the various techniques of collecting data and data sources that already exist. In this study triangulation was carried out by observation guidelines, interview guidelines and field notes. Whereas membercheck is done by repeating the outline of what was revealed by the informant at the end of the interview to ensure the data obtained from the interviews.

\section{RESEARCH RESULTS AND DISCUSSION Description of Preliminary Condition}

The results of the skill to speak English Students of Potensi Utama University prior to the research can be seen in the following table :

Table 4.1

Daily Repeat Value Preliminary Condition

\begin{tabular}{|c|c|c|c|c|}
\hline No. & Category & $\begin{array}{c}\text { Value } \\
\text { Range }\end{array}$ & Frequency & $\%$ \\
\hline 1 & Very good & $85-100$ & - & 0 \\
\hline 2 & Well & $75-84$ & 6 & 24 \\
\hline 3 & Enough & $60-74$ & 9 & 36 \\
\hline 4 & Less & $50-59$ & 8 & 32 \\
\hline 5 & Very less & $0-49$ & 2 & 8 \\
\hline \multicolumn{3}{|c|}{ total } & 25 & 100 \\
\hline
\end{tabular}

Source: Pre-cycle research results

Based on table 4.1 above shows that of the 25 number of students none of which fall into the very good category, and there are only 6 students (24\%) who will have the skill to speak in English in both categories. While those in the sufficient category are only 9 Most students (36\%). While in the less category there are as many as 8 students (32\%), and 2 Most students (8\%) are in the very poor category.

\subsection{Description of Cycle I}

Cycle I use the Total Physical Response method in a large group. At the beginning of learning, students are asked to translate instructions for making food or drinks in English in accordance with the provisions of the procedure text. At this stage, students are guided 
E-ISSN : 2540-8968

to be able to understand the concepts of the text being studied with the introduction of the generic and grammatical structures used.

Furthermore, the lecturer gave an example (modeling) of how to make food / drinks based on the instructions on the packaging carried by students through several videos so that students had an increasingly clear picture of procedure text. In this stage, the process of internalizing learning is ongoing. By looking directly at the process, students are invited directly to experience the learning done.

After students have a clear picture of what needs to be done, the next step is to work with several students in one group to practice a procedure text. It is hoped that, at this stage, students will be able to formulate text designs both in oral and written. With this group collaboration pattern, students have the opportunity to exchange knowledge and help one another. By using existing materials, based on the examples given by the lecturers, each group practices directly in front of the class with the tools needed.

The last stage of learning is that students are required to be able to design the text of the procedure independently by using the experiences they have gained in the previous learning stages. At this stage students are assigned to make a text procedure to make vanilla ice cream.

The assessment guidelines used to determine student success in speaking can be seen in the following table:

Table 4.2 Assessment Guidelines

\begin{tabular}{|l|l|l|}
\hline No & \multicolumn{1}{|c|}{ Rated aspect } & $\begin{array}{c}\text { Level } \\
\text { Scale }\end{array}$ \\
\hline 1 & $\begin{array}{l}\text { Language Factors: } \\
\text { a. } \begin{array}{l}\text { Pronunciation clarity and } \\
\text { articulation.(unclear, unclear, } \\
\text { clear, very clear) } \\
\text { b. Intonation accuracy, pressure } \\
\text { and volume. (not right, not right, } \\
\text { right, right) }\end{array}\end{array}$ & 1234 \\
& $\begin{array}{l}\text { Accuracy of structure usage, } \\
\text { vocabulary, and expression } \\
\text { (no right, not right, right, } \\
\text { right once) . }\end{array}$ & 1234 \\
d. $\begin{array}{l}\text { Fairness of the discourse } \\
\text { sequence. (very abnormal, } \\
\text { abnormal not normal, normal). }\end{array}$ & 1234 \\
\hline
\end{tabular}

\begin{tabular}{|c|c|c|}
\hline 2 & $\begin{array}{l}\text { Non-linguistic factors } \\
\text { a. Information accuracy. (very bad, } \\
\text { less accurate, accurate, } \\
\text { accurate fully). } \\
\text { b. Circuited a n deliverinformation } \\
\text { (very little, less, related, } \\
\text { related with fully). } \\
\text { c. Smoothness (halting, not } \\
\text { smooth, smooth, very smooth) } \\
\text { d. Style of pronunciation, attitude, } \\
\text { appearance, facial expression, } \\
\text { body language. (not right, not } \\
\text { right, right, very right) }\end{array}$ & $\begin{array}{l}1234 \\
1234\end{array}$ \\
\hline & & \\
\hline
\end{tabular}

Qualitative analysis of test results calculated in percentage with the following steps: a) applying earned value maha students, b) calculate the value of each aspect, c) calculating the average value, d) calculating the percentage value. Value is calculated using percent or called percentages correction by formula:

$$
\text { Student Value }=\frac{\text { Score of acquisition }}{\text { Maximum Score Amount }} \times 100
$$

Based on the guidelines for speaking skills assessment, it is known all-student skill in speaking with a very good, successful, successful enough, less successful, and unsuccessful. Students who succeed very well is most students who received grades 85-100, students who did well is most students who received grades $75-84$, is most successful students with enough category is most students who received grades 60-74, all-student managed by the unfavorable category, namely almighty students who received grades 50-59, and allsis wa unsuccessful namely self Mahasi whose grades 0-49. The results of student learning activities in the learning in Cycle I can be seen in the following table:

Table 4.3 Students' English Speaking Skill

Data Results In Cycle I

\begin{tabular}{|c|l|c|c|c|}
\hline No. & Category & $\begin{array}{c}\text { Value } \\
\text { Range }\end{array}$ & Frequency & $\boldsymbol{\%}$ \\
\hline 1 & Very good & $85-100$ & 1 & 4 \\
\hline 2 & Well & $75-84$ & 9 & 36 \\
\hline 3 & Enough & $60-74$ & 6 & 24 \\
\hline
\end{tabular}




\begin{tabular}{|c|l|c|c|c|}
\hline 4 & Less & $50-59$ & 8 & 32 \\
\hline 5 & Very less & $0-49$ & 1 & 4 \\
\hline \multicolumn{3}{|c|}{ Total } & $\mathbf{2 5}$ & $\mathbf{1 0 0}$ \\
\hline
\end{tabular}

Source: Cycle I research results

Based on table 4.3 above shows that of the 25 number of students included in the excellent category, there are 1 student $(4 \%)$ and only 9 students (36\%) who have the skill to speak English in good categories. While those in the sufficient category are only 6 great students (24\%). While in the less category there are as many as 8 all students (32\%), and I most students $(4 \%)$ are in the very poor category.

These results also indicate an increase in students' skill to speak English

\subsection{Description of Cycle II}

Cycle II is a revision of cycle I. The planning of actions that have been compiled by the researcher and colleagues collaborators is to use the Total Physical Response method in a small group. The material presented in this second cycle is procedural text material which is a continuation of the material discussed in the previous cycle. The results of observations about student learning activities in learning Cycle II English can be seen in the following graphs and tables :

Table 4.4 Students' English Speaking Skill Data in Cycle II

\begin{tabular}{|c|c|c|c|c|}
\hline No. & Category & $\begin{array}{c}\text { Value } \\
\text { Range }\end{array}$ & Frequency & $\%$ \\
\hline 1 & Very good & $85-100$ & 5 & 20 \\
\hline 2 & Well & $75-84$ & 12 & 48 \\
\hline 3 & Enough & $60-74$ & 5 & 20 \\
\hline 4 & Less & $50-59$ & 2 & 8 \\
\hline 5 & Very less & $0-49$ & 1 & 4 \\
\hline \multicolumn{3}{|c|}{ total } & 25 & 100 \\
\hline
\end{tabular}

Source: Results of Cycle II research

Based on table 4.4 above shows that of the 25 number of students included in the excellent category, there are 5 students (20\%), and 12 students (48\%) who have the skill to speak English in good categories. While those in category enough just 5 students $(20 \%)$. While in the poor category there were two great students $(8 \%)$, and 1 all- students (4\%) are in the category of very less

\subsection{Discussion}

The improvement of speaking skill in learning English with Total Physical Response to the students of Potensi Utama university was obtained by comparing the acquisition of students' abilities in the first cycle and the second cycle as follows:

Table 4.5. Comparison of Students' Speaking Skill in Pre-Cycle, Cycle 1 and Cycle II

\begin{tabular}{|c|c|c|c|c|}
\hline No & Research & Category & $\begin{array}{c}\text { The } \\
\text { number of } \\
\text { students }\end{array}$ & $\%$ \\
\hline 1 & $\begin{array}{c}\text { Preliminary } \\
\text { condition }\end{array}$ & $\begin{array}{c}\text { Complete } \\
\text { completed }\end{array}$ & 6 & $24 \%$ \\
\hline \multirow{2}{*}{2} & \multirow{2}{*}{ Cycle I } & Complete & 19 & $76 \%$ \\
\cline { 3 - 5 } & $\begin{array}{c}\text { Not } \\
\text { completed }\end{array}$ & 15 & $60 \%$ \\
\hline \multirow{2}{*}{3} & \multirow{2}{*}{ Cycle II } & Complete & 17 & $68 \%$ \\
\cline { 3 - 5 } & $\begin{array}{c}\text { Not } \\
\text { completed }\end{array}$ & 8 & $32 \%$ \\
\hline
\end{tabular}

Source: Results of the 2019 study

Based on the data from table 4.5, it can be seen that the percentage of the results of completeness of students' scores between the preliminary condition and the first cycle and the second cycle has increased. In the preliminary conditions the percentage of completeness in student grades is only $24 \%$. In the first cycle the percentage of completeness of students' scores increased to $40 \%$, while in the second cycle there was a significant increase to $68 \%$. If the comparison drawn between their speaking skill at the time of the preliminary conditions and after the implementation of the Total Physical Response method, then there is an increase by 53\% the skill to speak English of the students by using Total Physical Response method. This study therefore declared successful and it can be said that the use of the Total Physical Response method can improve the students' English speaking skill on the procedure text

\section{CONCLUSION}

Based on the results of these studies it can be concluded as follows:

1. From the results of the action as much as 2 (two) cycles for the Students of the Potensi 
Utama University, it was concluded that the use of the Total Physical Response method can improve the learning outcomes of students' English Speaking skill in the material Procedure text.

2. Student learning outcomes in learning each cycle has increased. This can be seen from the percentage of students who have achieved KKM which increases every cycle. The percentage of completeness of student learning outcomes in the cognitive realm of the first cycle was $53 \%$ and in the second cycle increased to $100 \%$, thus this study was declared successful and it can be said that the use of the Total Physical Response method can improve student learning outcomes in the text procedure.

\section{SUGGESTION}

Based on the conclusions of the use of the Total Physical Response method can improve the learning outcomes of English Language Students at Potensi Utama University in the procedure text material, the researcher provides several recommendations as follows:

1. For the university, it is expected to be able to apply the Total Physical Response method as an alternative in choosing learning methods for lecturers because this method can attract students' interest in learning, foster independent learning activities, fun, and also involve students' potential so that it is expected to improve the quality of learning.

2. For lecturers who will apply the Total Physical Response method in classroom learning, lecturers should form heterogeneous groups. This is intended to reduce the chance of students chatting when learning. In addition, if the lecturer applies this method, in the experimentation, the lecturer needs to do guidance every step. At the follow-up stage, the lecturer should involve noisy students and students whose grades are below the class average.

3. In this study there are still shortcomings such as time allocation which is not in accordance with the plan. Therefore, for the next researcher, it is hoped that it can improve time management in carrying out learning with the Total Physical Response method, especially when conducting the experiment.
1. DRPM (Directorate of Research and Community Service) of the General Directorate of Research Strengthening and Development, KEMENRISTEKDIKTI (Ministry of Reserach, Technology and Higher Education) for funding this reserach in accordance with the Reserach Contract for Fiscal Year 2019.

2. University of Potensi Utama for supporting and giving attention to this research.

\section{REFERENCES}

Arikunto, Suharsimi. 2010. Prosedur Penelitian Suatu Pendekatan Praktek. Jakarta: Rineka Cipta.

Dhieni, Nurbiana dkk. 2011. Metode Pengembangan Bahasa. Jakarta: Universitas Terbuka.

Didi Sukyadi, 2010. Pembelajaran Menyimak dan Berbicara. Bandung : Universitas. Pendidikan Indonesia

Elfa Febria Utami. 2013. Pengelolaan Pembelajaran Bahasa Inggris. Tesis. Bengkulu : Universitas Bengkulu

Fachrurrozi, Aziz dkk. 2016. Pembelajaran Bahasa Asing Tradisional dan Kontemporer. Jakarta: Raja Grafindo

Iskandarwassid dan Dadang Sunendar, 2011. Strategi Pembelajaran Bahasa, (Bandung: PT Remaja Rosdakarya.

Mahyuddin, Erta. 2010. Pembelajaran Bahasa Asing Metode Tradisional \& Kontemporer. Jakarta Timur: Bania Publishing

Nurjanah, Rosita. 2016. Penggunaan Metode Total Physical Response (TPR) Untuk Meningkatkan Vocabulary Bahasa Inggris. Universitas Sebelas Maret Surakarta

Solikhah, Imroatus. 2015. Reading and Writing as Academic Literacy in EAP Program of Indonesian Learners. Jakarta : Dinamika Ilmu

Suwandi, Sarwiji, 2009. Penelitian Tindakan Kelas (PTK) dan Penulisan Karya Ilmiah, Surakarta: Panitia Sertifikasi Guru Rayon 13 FKIP UNS Surakarta

\section{ACKNOWLEDGEMENTS}

I would like to thank 
BAHTERA: Jurnal Pendidikan Bahasa dan Sastra, Volume 18 Nomor 2 Juli 2019 http://journal.unj.ac.id/unj/index.php/bahtera/

P-ISSN : 0853-2710

E-ISSN : 2540-8968 